\title{
Good Corporate Governance sebagai Pemoderasi Pengaruh Financial Distress pada Opini Audit Going Concern
}

\author{
Ketut Memi Wulandari ${ }^{1}$ \\ Ketut Muliartha ${ }^{2}$ \\ ${ }^{1,2}$ Fakultas Ekonomi dan Bisnis, Universitas Udayana (Unud), Bali, Indonesia \\ e-mail: memiwulandari4@gmail.com
}

\begin{abstract}
ABSTRAK
Penelitian ini menggunakan perusahaan manufaktur yang terdaftar di Bursa Efek Indonesia sebagai objek penelitian. Jumlah sampel sebanyak 210 dengan menggunakan metode purposive sampling. Pengumpulan data dilakukan menggunakan dokumentasi. Teknik analisis data yang digunakan adalah Moderated Regression Analysis. Berdasarkan hasil analisis, ditemukan bahwa penerapan good corporate governance pada perusahaan mampu memperlemah pengaruh financial distress pada opini audit going concern. Implikasi hasil penelitian mendukung teori sinyal yang terlihat pada financial distress yang cenderung memberikan sinyal kepada auditor untuk memberikan opini audit going concern. Hasil penelitian juga mendukung teori keagenan dimana kecenderungan terjadinya asimetri informasi antara agen dan prinsipal terlebih pada perusahaan yang mengalami financial distress.
\end{abstract}

Kata kunci: Financial distress, good corporate governance, opini audit going concern.

\begin{abstract}
This research uses manufacturing companies listed on the Indonesia Stock Exchange as research's objects. The number of samples are 210 with using the purposive sampling method. Data collection is done using documentation. The data analysis technique used is Moderated Regression Analysis. Based on the results of the analysis, it was found that the application of good corporate governance to the company is able to weaken the influence of financial distress on the going concern audit opinion. The implications of the results of the study support the signal theory seen in the results of the financial distress which tends to signal the auditor to give a going-concern audit opinion. The results of the study also support agency theory where the tendency for information asymmetry between agents and principals, especially for companies in experience financial distress.
\end{abstract}

Keywords: Financial distress, good corporate governance, going-concern audit opinion.

\section{PENDAHULUAN}

Simunic (1994) dalam Made, et al. (2017) mengenai reaksi investor terhadap opini audit yang memuat informasi kelangsungan hidup perusahaan bedasarkan pengungkapan hasil analisis laporan keuangan. Penelitian tersebut membuktikan bahwa ketika investor melakukan investasi maka mereka perlu mengetahui kondisi keuangan perusahaan dengan melihat laporan auditor, khususnya 
mengenai kelangsungan usaha. Pengguna laporan keuangan selalu ingin mengetahui sejauh mana suatu perusahaan mampu menjaga kelangsungan usahanya setelah diaudit oleh Akuntan Publik.

Statement of Financial Accounting Concepts (SFAC) No. 1 menyebutkan tujuan utama laporan keuangan yaitu menyediakan informasi yang berguna dalam pembuatan keputusan bisnis dan ekonomi. Auditor akan memberikan early warning mengenai financial distress dari perusahaan kepada pengguna laporan keuangan (Chen dan Church, 1996). Sebagian besar pengguna investor menganggap laporan keuangan yang telah mendapat opini wajar tanpa pengecualian merupakan satu jaminan atas kondisi keuangan perusahaan yang sehat. Perusahaan yang sehat diyakini dapat mempertahankan usahanya dalam waktu yang panjang. Made et al. (2017) menyatakan bahwa ketika suatu perusahaan mengalami kesulitan keuangan bahkan kegagalan bisnis hingga terancam bangkrut maka perusahaan tersebut diyakini mengalami masalah, sehingga perusahaan tersebut diragukan dalam mempertahankan keberlangsungan hidupnya. Kondisi perusahaan yang mengalami kesulitan dan terancam bangkrut dikenal dengan financial distress.

Penelitian Made et al. (2017) membuktikan bahwa ketika perusahaan mengalami financial distress, maka perusahaan tersebut berpeluang mendapatkan opini audit going concern dari auditor karena keberlangsungan hidup perusahaan yang diragukan. Kasus PT Asia Natural Resources Tbk yang mendapatkan opini audit going concern yang pada akhirnya delisiting dari Bursa Efek Indonesia pada tahun 2014. Hal ini dikarenakan perusahaan tersebut tidak bisa memenuhi 
ketentuan bursa dan sahamnya disuspensi sejak 22 Mei 2014. Perseroan juga memiliki tunggakan Rp110 juta atas denda BEI. Kinerja keuangan perseroan juga memburuk. Pada semester I-2014 perseroan tidak membukukan penjualan sama sekali sehingga menderita kerugian hingga Rp357,33 miliar (finance.detik.com). Selain financial distress, opini audit going concern juga dipengaruhi oleh tata kelola perusahaan (Arisman, 2016).

Arisman (2016) menyatakan bahwa good corporate governance merupakan sistem mengenai bagaimana suatu organisasi dikelola dan dikendalikan. PER01/MBU/2011 tentang Penerapan Tata Kelola Perusahaan yang Baik (good corporate governance) menyatakan bahwa terdapat 5 (lima) prinsip good corporate governance yaitu transparansi, akuntabilitas, pertanggungjawaban, kemandirian dan kewajaran. Penelitian ini menggunakan 3 proksi yakni proporsi dewan komisaris independen, kepemilikan institusional dan kepemilikan manajerial.

Teori sinyal menyatakan informasi penting bagi investor dan pelaku bisnis (Spence, 1973). Teori sinyal akan membantu perusahaan selaku agen, pemilik, dan pihak luar perusahaan untuk mengurangi asimetri informasi dengan menghasilkan informasi keuagan yang disertai dengan pengungkapan berkualitas dan terintergritas (Dewi, 2018). Selain itu, meningkatkan keyakinan pihak prinsipal mengenai informasi yang terkandung dalam laporan keuangan, perusahaan menggunakan pihak independen yang profesional untuk memberikan pendapat mengenai laporan keuangan perusahaan. Informasi yang disajikan dapat berupa good news atau bad news. 
Teori agensi pertama kali dikemukakan oleh Jensen et al., (1976) yang menyatakan bahwa teori keagenan merupakan teori ketidaksamaan kepentingan antara prinsipal dan agen. Hubungan antara prinsipal dan agen dapat mengarah pada kondisi ketidakseimbangan informasi (asymmetrical information) karena agen berada pada posisi yang memiliki informasi yang lebih banyak tentang perusahaan dibandingkan dengan prinsipal (Richardson, 1998). Kondisi ini memberikan kesempatan pada agen untuk menggunakan informasi yang diketahuinya untuk memanipulasi pelaporan keuangan sebagai usaha untuk memaksimalkan kemakmurannya (Nurhaeni, 2010).

Kemungkinan terjadinya manipulasi yang dilakukan oleh agen, membuat diharuskan adanya pihak yang independen sebagai mediator antara agen dan prinsipal. Pihak independensi ini berfungsi untuk memonitor perilaku agen apakah bertindak sesuai dengan keinginan prinsipal (Dewayanto, 2011). Auditor merupakan pihak independen yang menjembatani hubungan antara prinsipal dan agen. Auditor mempunyai tugas untuk mengawasi kinerja manajemen apakah telah bertindak sesuai dengan kepentingan prinsipal melalui laporan keuangan (Ayu, 2016).

Pernyataan Standar Akuntansi Keuangan No 1 menyatakan bahwa laporan keuangan adalah suatu penyajian terstruktur dari posisi keuangan dan kinerja keuangan suatu entitas. Laporan keuangan disusun bertujuan menyediakan informasi keuangan perusahaan kepada pihak-pihak berkepentingan sebagai bahan pertimbangan di dalam mengambil keputusan (Sadewi, 2016). Laporan keuangan 
juga merupakan bentuk tanggungjawab manajemen atas penggunaan sumber daya yang telah dipercayakan kepada mereka.

Menurut Haryono (2013) audit adalah suatu proses sistematis untuk memperoleh dan mengevaluasi bukti tentang tindakan dan kejadian ekonomi yang berkaitan dengan asersi secara obyektif untuk menentukan tingkat kepatuhan antara asersi dengan ketetapan kriteria dan mengomunikasikan hasilnya kepada pihak-pihak yang berkepentingan. Standar Profesional Akuntan Publik SA Seksi 110 menyatakan tujuan audit atas laporan keuangan oleh auditor independen pada umumnya adalah untuk menyatakan pendapat tentang kewajaran dalam semua hal yang material, posisi keuangan, hasil usaha, perubahan ekuitas, dan arus kas sesuai dengan prinsip akuntansi yang berlaku umum di Indonesia. Auditor menggunakan laporan auditor sebagai media menyatakan pendapat atau tidak memberikan pendapat. Auditor tidak dibenarkan memihak kepentingan siapapun dan mudah dipengaruhi, serta terbebas dari kewajiban dan kepentingan dengan kliennya.

Opini audit diberikan oleh auditor melalui beberapa tahap audit sehingga auditor dapat memberikan kesimpulan pada opini yang harus diberikan atas laporan keuangan yang diaudit. Terdapat lima jenis opini audit (Mulyadi, 2010), yaitu: pendapat wajar tanpa pengecualian (unqualified opinion), pendapat wajar tanpa pengecualian dengan bahasa penjelas (unqualified opinion with explanatory language), pendapat wajar dengan pengecualian (qualified opinion), pendapat tidak wajar (adverse opinion), tidak memberikan pendapat (disclaimer of opinion) 
Opini audit going concern adalah opini auditor mengenai kemampuan perusahaan mempertahankan kelangsungan hidupnya. Laporan audit dengan modifikasi going concern merupakan suatu indikator bahwa berdasarkan sudut pandang auditor ditemukan risiko auditee tidak dapat mempertahankan kelangsungan usahanya (Rakatenda, 2016).

Auditor dalam memberikan opini audit going concern perlu mempertimbangkan beberapa hal, yaitu hasil dari operasi, kondisi ekonomi yang mempengaruhi perusahaan, kemampuan membayar hutang, dan kebutuhan likuiditas di masa yang akan datang (Januarti, 2009). Setelah dikeluarkannya SAS 59, sekitar 40\%-50\% perusahaan yang mengalami kebangkrutan ternyata telah menerima opini audit going concern atas laporan keuangan terkahir sebelum kebangkrutan (Rodger, et al., 2009 dalam Dewi, 2018).

Opini going concern yang menyebutkan adanya keraguan auditor pada perusahaan dalam upaya melanjutkan usahanya merupakan sinyal bahwa perusahaan sedang menghadapi masalah going concern, seperti masalah financial distress. Financial distress merupakan tahap penurunan kondisi keuangan yang dialami perusahaan sebelum kebangkrutan atau likuidasi (Platt dan Platt, 2002). Kondisi financial distress pada perusahaan disebabkan manajemen perusahaan yang buruk, ekspansi yang kurang bijaksana, utang yang berlebih, sengketa besar, dan kontrak yang tidak menguntungkan (Emery, et al., 2007).

Kondisi financial distress dapat menyebabkan perusahaan mengalami arus kas negatif, rasio keuangan yang buruk, gagal memenuhi perjanjian utang yang ada dan pada akhirnya mengarahkan perusahaan pada kebangkrutan, sehingga 
going concern perusahaan diragukan (Agung, et al.,., 2018). Keraguan pada going concern perusahaan akan mendorong auditor untuk mengeluarkan opini audit going concern. Pemberian opini audit going concern juga dapat dipengaruhi oleh good corporate governance yang diterapkan oleh perusahaan (Arisman, 2016).

Penerapan corporate governance erat kaitannya dengan going concern problems. Corporate governance yang buruk menandakan bahwa perusahaan tidak dijalankan dan diawasi dengan baik, sehingga menyebabkan buruknya kinerja keuangan perusahaan dan masalah keuangan. Hal tersebut mengakibatkan keraguan auditor atas keberlangsungan hidup perusahaan dan cenderung memberikan opini audit going concern. Pemberian opini audit going concern dapat dicegah dan diatasi dengan adanya tata kelola perusahaan yang baik (good corporate governance).

Penelitian ini menggunakan 3 proksi dalam meneliti good corporate governance sebagai variabel moderasi, yaitu dewan komisaris independen, kepemilikan institusional dan kepemilikan manajerial. Berdasarkan Keputusan Direksi BEI nomor: KEP-399/BEJ/07-2001, komisaris independen bertanggungjawab untuk mengawasi kebijakan dan tindakan direksi, dan memberikan nasihat kepada dewan direksi jika diperlukan. Berdasarkan hal tersebut, keberadaan dewan komisaris independen sangat diperlukan guna mengawasi kinerja direksi dalam menjalankan perusahaan selain dewan komisaris di perusahaan.

Kepemilikan institusional merupakan bagian dari struktur kepemilikan dalam perusahaan (Helena, 2016). Kepemilikian institusional adalah kepemilikan 
saham biasa oleh institusi. Tingginya kepemilikan oleh investor instituional akan mendorong aktivitas monitoring karena besarnya kekuatan voting mereka yang akan mempengaruhi kebijakan manajemen (Schleifer dan Vinshy, 1986). Kepemilikan manajerial merupakan mekanisme corporate governance sebagai salah satu monitoring yang dapat membawa pada kualitas pelaporan yang lebih baik (Setiawan, 2011 dalam Agusti, 2013).

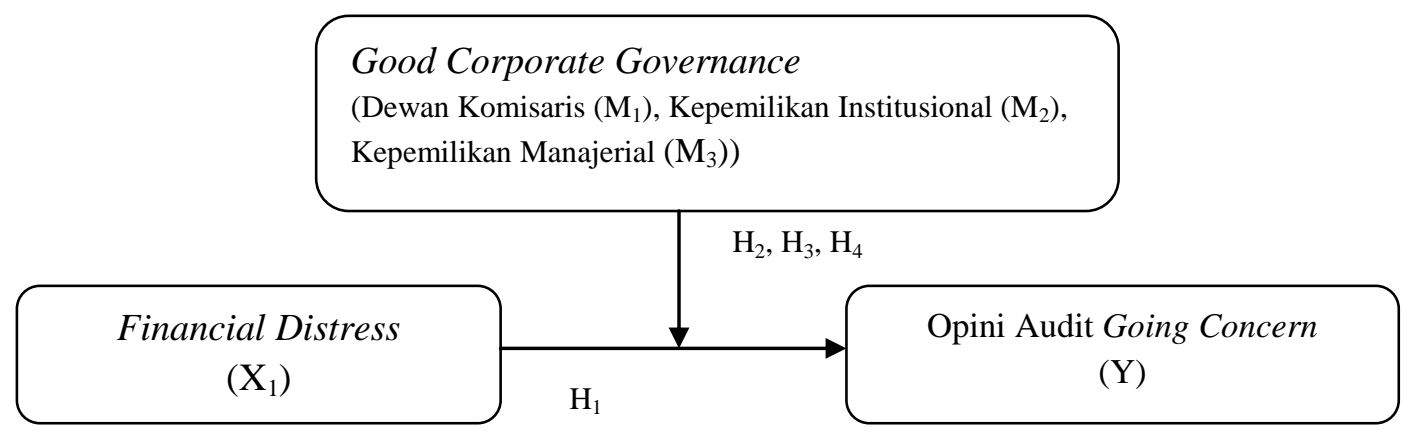

Sumber: Data diolah, 2019

\section{Gambar 1. Kerangka Konseptual}

Memburuknya kondisi keuangan perusahaan ditandai dengan menurunnya kemampuan pemenuhan kewajiban jangka pendek perusahaan. Menurunnya kondisi keuangan tentu berdampak pada keberlangsungan perusahaan. Ketika perusahaan mengalami kesulitan keuangan bahkan kegagalan bisnis hingga terancam bangkrut maka perusahaan tersebut diyakini mengalami masalah dan diragukan dalam mempertahankan kelangsungan hidupnya (Made et al., 2017).

Penelitian yang dilakukan (Januarti, 2009) menunjukkan hasil financial distress tidak berpengaruh pada pemberian opini audit going concern sedangkan penelitian Setiawan (2011) dalam Adjani (2013) menunjukkan hasil bahwa financial distress berpengaruh positif pada pemberian opini audit going concern. Penelitian yang dilakukan lainnya yang Yuliani (2017) dan Dewi (2018) 
menunjukkan hasil bahwa financial distress berpengaruh negatif pada opini audit going concern dengan menggunakan model Altman Z-Score pada penerimaan opini audit going concern. Hal tersebut karena semakin rendah nilai Z-Score maka semakin besar kemungkinan perusahaan tersebut akan menerima opini audit going concern. Berdasarkan uraian diatas, hipotesis yang dapat dirumuskan dalam penelitian ini adalah sebagai berikut:

$\mathrm{H}_{1}$ : Financial Distress berpengaruh negatif pada Opini Audit Going Concern.

Kecenderungan moral hazard yang dilakukan agen akan meningkat ketika pengawasan principal melemah dan independensi dewan komisaris juga cenderung melemah (Mulyani, dkk., 2012). Dewan komisaris independen melakukan monitoring terhadap kinerja dewan direksi yang dipimpin oleh CEO dan bertindak independen tanpa adanya pengaruh dari pihak-pihak dari dalam perusahaan. Pengaruh kondisi financial distress terhadap penerimaan opini audit going concern akan diperlemah dengan peningkatan proporsi dewan komisaris independen karena pengawasan akan semakin baik karena pihak independen cenderung lebih adil dalam melakukan pengawasan sehingga hal tersebut akan meningkatkan kinerja perusahaan dan memperpanjang keberlangsungan hidup perusahaan. Penelitian lainnya yang dilakukan oleh Emrinaldi (2007), Hong-xia et.al (2008) dan Agusti (2013) menunjukkan bahwa proporsi dewan komisaris berpengaruh negatif pada financial distress. Berdasarkan uraian diatas, hipotesis yang dapat dirumuskan dalam penelitian ini adalah sebagai berikut:

$\mathrm{H}_{2}$ : Proporsi Dewan Komisaris memoderasi pengaruh Financial Distress pada Opini Audit Going Concern. 
Adanya kepemilikan institusional seperti kepemilikan saham perusahaan oleh semua jenis institusi akan meningkatkan dorongan dan kekuatan suara institusi dalam mengawasi manajemen yang mengakibatkan munculnya motivasi yang lebih besar bagi manajemen perusahaan. Hal tersebut dapat dijadikan pertimbangan oleh auditor dalam menilai keberlangsungan perusahaan yang tengah mengalami financial distress. Pengaruh financial distress akan melemah ketika perusahaan meningkatkan kepemilikan institusional karena peningkatan kepemilikan institusional akan meningkatkan pengawasan terhadap keputusan manajemen sehingga mengurangi potensi kebangkrutan yang dapat mengimplikasi auditor untuk tidak memberikan opini audit going concern pada perusahaan. Berdasarkan uraian di atas, hipotesis yang dapat dirumuskan adalah sebagai berikut:

$\mathrm{H}_{3}$ : Kepemilikan Institusioanal memoderasi pengaruh Financial Distress pada Opini Audit Going Concern.

Kepemilikan manajerial dapat mengurangi konflik kegaenan antara manajer dengan pemegang saham, karena besar kecilnya kepemilikan manajerial menggambarkan adanya kesamaan kepentingan antara manajer dengan pemegang saham dalam perusahaan. Pengaruh financial distress akan melemah dengan meningkatkan proporsi kepemilikan manajerial pada perusahaan karena manajer akan cenderung memiliki tanggung jawab yang lebih besar, mengambil keputusan terbaik untuk perusahaan serta melaporkan laporan keuangan dengan informasi yang benar. Berdasarkan uraian di atas, hipotesis yang dapat dirumuskan adalah sebagai berikut: 
$\mathrm{H}_{4}$ : Kepemilikan Manajerial memoderasi pengaruh Financial Distress pada Opini Audit Going Concern.

\section{METODE PENELITIAN}

Penelitian dilakukan pada perusahaan manufaktur yang terdaftar di Bursa Efek Indonesia dengan mengakses laman www.idx.co.id untuk mendapatkan informasi yang diperlukan tentang perusahaan manufaktur serta untuk memperoleh laporan keuangan tahunan perusahaan. Obyek penelitian dalam penelitian ini berfokus pada opini audit going concern yang terdapat dalam laporan auditor independen pada perusahaan manufaktur yang terdaftar di Bursa Efek Indonesia dari tahun 2015-2017. Alasan dipilihnya sektor manufaktur sebagai objek penelitian karena jumlah perusahaan manufaktur dalam BEI relatif banyak sehingga diperkirakan dapat memenuhi jumlah minimal sampel yang memenuhi syarat yang digunakan sebagai bahan penelitian.

Variabel-variabel yang diidentifikasi dalam penelitian ini dikelompokkan sebagai berikut:Variabel dependen dalam variabel ini adalah opini audit going concern (Y). Variabel independen dalam penelitian ini adalah financial distress $\left(\mathrm{X}_{1}\right)$. Variabel moderasi dalam penelitian ini adalah proporsi dewan komisaris independen $\left(\mathrm{M}_{1}\right)$, kepemilikan institusional $\left(\mathrm{M}_{2}\right)$ dan kepemilikan manajerial $\left(\mathrm{M}_{3}\right)$.

Financial distress merupakan kondisi perusahaan mengalami kesulitan keuangan dan terancam bangkrut (Made et al., 2017). Financial distress dalam penelitian ini diukur dengan menggunakan model Altman Z-Score. Model Altman (Z-Score) adalah model yang mengkaji pemanfaatan analisis rasio keuangan sebagai alat untuk memprediksi kebangkrutan. Formula ini dihasilkan oleh 
Altman pada tahun 1968 dan mengalami perubahan pada tahun 1984 menjadi formula sebagai berikut:

$$
\mathrm{Z}=0,717 \mathrm{~T}_{1}+0,847 \mathrm{~T}_{2}+3,107 \mathrm{~T}_{3}+0,42 \mathrm{~T}_{4}+0,998 \mathrm{~T}_{5}
$$

Keterangan

$\mathrm{T}_{1}=$ Working Capital to Total Assets Ratio

$\mathrm{T}_{2}=$ Retained Earning to Total Assets Ratio

$\mathrm{T}_{3}=$ Earning Before Interest and Taxes to Total Assets Ratio

$\mathrm{T}_{4}=$ Market Value of Equity to Book Value of Liability

$\mathrm{T}_{5}=$ Sales to Total Assets

Peraturan BEJ tanggal 1 Juli 2000 mewajibkan perusahaan yang listing di Bursa Efek Indonesia harus memiliki komisaris dengan syarat proporsi jumlah komisaris independen dibandingkan dengan selurh jumlah dewan komisaris adalah sebesar 30\%. Proporsi dewan komisaris diukur dengan persentase jumlah anggota dewan komisaris yang berasal dari luar perusahaan dibandingkan dengan jumlah seluruh anggota dewan komisaris perusahaan.

Proporsi dewan komisaris independen $=\frac{\text { jumlah komisaris independen }}{\text { jumlah komisaris perusahaan }} \times 100 \%$.

Kepemilikan institusional merupakan kepemilikan perusahaan oleh semua jenis institusi asing maupun dalam negeri yang bergerak dalam bidang keuangan maupun non-keuangan (Agusti, 2013). Kepemilikan institusional dalam penelitian ini diukur dengan menggunakan skala rasio melalui jumlah salam yang dimiliki institusional dibandingkan dengan total saham perusahaan.

$$
\text { Kepemilikan Institusional }=\frac{\text { jumlah saham yang dimiliki pihak institusi }}{\text { jumlah saham perusahaan }} \times 100 \% \text {. }
$$

Kepemilikan manajerial merupakan kepemilikan perusahaan oleh manajer perusahaan. kepemilikan manajerial diukur dengan menggunakan skala rasio 
melalui jumlah salam yang dimiliki manajer dibandingkan dengan total saham perusahaan.

Kepemilikan Manajerial $=\frac{\text { jumlah saham yang dimiliki pihak manajer }}{\text { jumlah saham perusahaan }} \times 100 \%$

Populasi dalam penelitian ini adalah seluruh perusahaan manufaktur yang terdaftar di Bursa Efek Indonesia (BEI) pada periode 2014-2017 yang berjumlah 149 perusahaan (www.idx.co.id diakses 13 November 2018). Metode penentuan sampel yang digunakan dalam penelitian ini adalah purposive sampling.

Kriteria sampel penelitian ini yaitu begai berikut. Perusahaan manufaktur yang terdaftar di Bursa Efek Indonesia selama 2015-2017. Perusahaan manufaktur yang menerbitkan laporan keuangan dan laporan tahunan secara terus menerus di Bursa Efek Indonesia selama 2015-2017. Perusahaan manufaktur yang menerbitkan laporan tahunan yang menyediakan data yang dibutuhkan mengenai variabel-variabel penelitian, yaitu financial distress, komisaris independen, kepemilikan institusional dan kepemilikan manajerial.

Penelitian ini menggunakan metode dokumentasi dalam pengumpulan data. Dokumentasi dilakukan dengan mencari, mengumpulkan, mencatat, dan mengkaji data sekunder. Jenis data dalam penelitian ini adalah data sekunder berupa angka atau data kuantitatif yang bersumber dari laporan keuangan perusahaan manufaktur yang terdaftar di BEI. Data kualitatif dalam penelitian ini adalah opini audit pada laporan keuangan perusahaan manufaktur yang terdaftar di BEI.

Teknik analisis data merupakan kegiatan yang dilakukan setelah seluruh data telah terkumpul. Regresi logistik adalah regresi yang digunakan untuk menguji kemampuan variabel independen memprediksi probabilitas variabel dependen. 
Analisis regresi logistik digunakan karena variabel terikatnya merupakan variabel dummy. Tahapan dalam pengujian dengan menggunakan uji regresi logistik adalah sebagai berikut: Adapun model regresi logistik penelitian ini sebagai berikut:

$$
\mathrm{Y}=\alpha+\beta_{1} X_{1}+\mathrm{e}
$$

Keterangan:

$\mathrm{Y} \quad$ = perusahaan yang menerima opini audit going concern (kode 1) dan yang menerima opini non-going concern (kode 0)

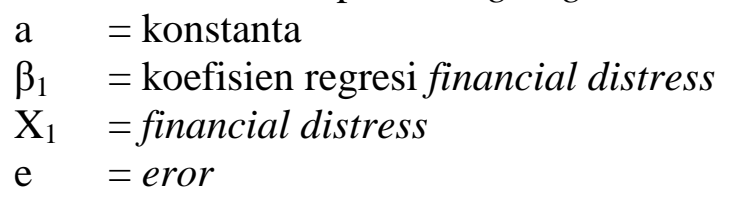

Analisis Regresi Moderasi/Moderated Regression Analysis (MRA) adalah aplikasi khusus regresi berganda linear dimana dalam persamaan regresinya mengandung unsur interaksi (perkalian dua atau lebih variabel independen) (Ghozali, 2013 dalam Arisman, 2016).

$\mathrm{Y}=\alpha+\beta_{1} X_{1}+\beta_{2} M_{1}+\beta_{3} \mathrm{M}_{2}+\beta_{4} M_{3}+\beta_{5} X_{1} \mathrm{M}_{1}+\beta_{6} X_{1} M_{2}+\beta_{7} X_{1} \mathrm{M}_{3}+\varepsilon . .(6)$

Keterangan:

$\mathrm{Y} \quad$ = perusahaan yang menerima opini audit going concern (kode 1) dan yang menerima opini non-going concern (kode 0)

a $\quad=$ konstanta

$\beta_{1}-\beta_{7}=$ koefisien regresi

$\mathrm{X}_{1} \quad=$ financial distress

$\mathrm{M}_{1}=$ proporsi dewan komisaris independen

$\mathbf{M}_{2}=$ kepemilikan institusional

$\mathrm{M}_{3}=$ kepemilikan manajerial

$\varepsilon=$ eror 


\section{HASIL PEMBAHASAN}

Populasi dalam penelitian ini adalah seluruh perusahaan manufaktur yang terdaftar di BEI pada tahun 2015 sampai dengan 2017 yaitu sebanyak 149 perusahaan. Pengambilan sampel dalam penelitian ini menggunakan teknik non probability sampling dan metode pengambilan sampel yang digunakan dalam penelitian ini adalah metode purposive sampling sehingga sampel yang diperoleh sebanyak 70 sampel dan jumlah data amatan dengan pengamatan selama 3 tahun sebanyak 210 sampel perusahaan. perusahaan yang menjadi sampel penelitian ditentukan melalui proses penyeleksian dengan beberapa kriteria yang telah ditetapkan seperti yang disajikan dalam Tabel 1.

Tabel 1.

\section{Ringkasan Perolehan Sampel Penelitian}

\begin{tabular}{llc}
\hline No & \multicolumn{1}{c}{ Kriteria } & Jumlah \\
\hline 1 & $\begin{array}{l}\text { Perusahaan manufaktur yang terdaftar di BEI selama periode 2015-2017 } \\
2\end{array}$ & $\begin{array}{l}\text { Perusahaan manufaktur yang tidak menerbitkan laporan keuangan pada } \\
\text { periode 2015-2017 }\end{array}$ \\
3 & $\begin{array}{l}\text { Perusahaan manufaktur yang tidak menyediakan data yang dibutuhkan } \\
\text { mengenai variabel-variabel penelitian, yaitu komisaris independen, }\end{array}$ & $(30)$ \\
& $\begin{array}{l}\text { kepemilikan institusional dan kepemilikan manajerial. } \\
4\end{array}$ & Jumlah perusahaan yang terpilih sebagai sampel \\
5 & Total sampel dalam tiga tahun penelitian & 70 \\
\hline Sumber: Data diolah, 2019 & 210
\end{tabular}

Berdasarkan Tabel 2 dapat dijelaskan sebagai berikut hasil analisis deskriptif untuk variabel financial distress yang diukur menggunakan Altman-Z Score menunjukkan bahwa nilai minimumnya sebesar $-9,9999$ dan nilai maksimumnya sebesar 21,6500. Nilai minimum memiliki arti bahwa kondisi keuangan perusahaan terburuk pada score $-9,999$ sedangkan nilai maksimum mengartikan bahwa kondisi keuangan perusahaan terbaik pada score 21,65000. Nilai rata-rata financial distress adalah sebesar 2,138905 menunjukkan bahwa rata-rata sebagian besar perusahaan manufaktur berada pada grey area atau bisa 
diartikan dalam kondisi yang tidak buruk namun perlu diperhatikan dengan seksama sebagai upaya pencegahan terjadinya financial distress pada perusahaan. Nilai standar deviasi financial distress adalah sebesar 2,4707014 menunjukkan bahwa nilai standar deviasi lebih besar daripada nilai rata-rata, sehingga tingkat sebaran data pada variabel financial distress relatif tinggi.

Tabel 2.

Hasil Uji Statistik Deskriptif

\begin{tabular}{llllll}
\hline & $\mathrm{N}$ & Minimum & Maksimum & Mean & Std. Deviation \\
\hline Financial Distress & 210 & -9.9999 & 21.6500 & 2.138905 & 2.4707014 \\
$\begin{array}{l}\text { Dewan Komisaris } \\
\text { Independen }\end{array}$ & 210 & .0000 & .8000 & .392596 & .1054068 \\
$\begin{array}{l}\text { Kepemilikan } \\
\text { Institusional }\end{array}$ & & & & & \\
Kepemilikan Manajerial & 210 & .3222 & .9921 & .748249 & .1603621 \\
Opini Going Concern & 210 & .0000 & .3790 & .027715 & .0697428 \\
Valid N (listwise) & 210 & .00 & 1.00 & .0524 & .22333 \\
\hline Sumber: Data diolah, 2019 & & & & & \\
\hline
\end{tabular}

Hasil analisis deskriptif variabel dewan komisaris independen menunjukkan nilai minimum sebesar 0,000 dan nilai maksimum sebesar 0,8000. Nilai minimum memiliki arti bahwa perusahaan paling rendah tidak memiliki dewan komisaris independen sedangkan nilai maksimum memiliki arti bahwa perusahaan paling tinggi memiliki 0,8000 komisaris independen dari keseluruhan dewan komisaris. Nilai rata-rata dewan komisaris independen sebesar 0,392596 menunjukkan bahwa rata-rata dewan komisaris perusahaan terdiri dewan komisaris independen sebesar 40 persen dari total keseluruhan dewan komisaris. Hal ini telah memenuhi standar minimum komposisi dewan komisaris independen dalam perusahaan yakni paling sedikit 30 persen dari total komisaris perusahaan. Nilai standar deviasi dewan komisaris independen adalah sebesar 0.1054068 menunjukkan bahwa nilai standar deviasi lebih kecil daripada nilai rata-rata, sehingga tingkat sebaran data pada variabel dewan komisaris independen relatif rendah. 
Hasil analisis deskriptif variabel kepemilikan institusional menunjukkan nilai minimum sebesar 0,3222 dan nilai maksimum sebesar 0,9921 . Nilai minimum memiliki arti bahwa kepemilikan institusional terendah pada perusahaan sebesar 0,3222 sedangkan nilai maksimum memiliki arti bahwa kepemilikan institusional tertinggi pada perusahaan sebesar 0,9921. Nilai rata-rata kepemilikan institusional sebesar 0,748249 menunjukkan bahwa rata-rata kepemilikan institusional bertindak sebagai pemegang saham mayoritas di perusahaan manufaktur. Nilai standar deviasi kepemilikan institusional adalah sebesar 0.1603621 menunjukkan bahwa nilai standar deviasi lebih kecil daripada nilai rata-rata, sehingga tingkat sebaran data pada variabel kepemilikan institusional relatif rendah.

Hasil analisis deskriptif variabel kepemilikan manajerial menunjukkan nilai minimum sebesar 0,000 dan nilai maksimum sebesar 0,3790 . Nilai minimum memiliki arti bahwa kepemilikan manajerial terendah pada perusahaan sebesar 0,000 sedangkan nilai maksimum memiliki arti bahwa kepemilikan manajerial tertinggi pada perusahaan sebesar 0,3790 . Nilai rata-rata kepemilikan manajerial sebesar 0,027715 menunjukkan bahwa rata-rata kepemilikan manajerial bertindak sebagai pemegang saham minoritas di perusahaan manufaktur. Nilai standar deviasi kepemilikan institusional adalah sebesar 0.697428 menunjukkan bahwa nilai standar deviasi lebih besar daripada nilai rata-rata,

Hasil analisis deskriptif variabel opini going concern menunjukkan nilai minimum sebesar 0,00 dan nilai maksimum sebesar 1,00. Berdasarkan penelitian yang dilakukan pada perusahaan manufaktur yang terdaftar di BEI tahun 2015- 
2017 menunjukkan hanya 11 sampel perusahaan yang menerima opini audit going concern. Nilai rata-rata opini going concern sebesar 0,0524 menunjukkan bahwa lebih banyak perusahaan manufaktur yang tidak memperoleh opini going concern. Nilai standar deviasi kepemilikan institusional adalah sebesar 0,22333 menunjukkan bahwa nilai standar deviasi lebih kecil daripada nilai rata-rata, sehingga tingkat sebaran data pada variabel opini going concern relatif tinggi.

Tabel 3.

Hasil Uji Normalitas

\begin{tabular}{ll}
\hline & Unstandardized Residual \\
\hline $\mathrm{N}$ & 210 \\
Run Test Normalitas & 0,486 \\
Asymp. Sig. (2-tailed) & 0,627 \\
\hline Sumber: Data diolah, 2019
\end{tabular}

Sumber: Data diolah, 2019

Berdasarkan Tabel 3. dapat dilihat bahwa nilai Asymp. Sig. (2-tailed) sebesar 0,627. Hasil tersebut mengindikasikan bahwa model persamaan regresi tersebut berdistribusi normal karena nilai Asymp. Sig. (2-tailed) 0,627 lebih besar dari nilai alpha 0,05 .

Tabel 4.

Hasil Uji Heteroskedastisitas

\begin{tabular}{llllll}
\hline Model & \multicolumn{2}{l}{$\begin{array}{l}\text { Unstandardized } \\
\text { Coefficients }\end{array}$} & \multicolumn{2}{l}{$\begin{array}{l}\text { Standardized } \\
\text { Coefficients }\end{array}$} & \\
\cline { 2 - 5 } & B & Std. Error & Beta & \multicolumn{1}{c}{ S } & Sig. \\
\hline 1 (Constant) & .045 & .067 & & .677 & .499 \\
Financial Distress & .025 & .019 & .526 & 1.315 & .190 \\
Dewan Komisaris Independen & .005 & .120 & .004 & .040 & .968 \\
Kepemilikan Institusional & .040 & .079 & .054 & .511 & .610 \\
Kepemiliknan Manajerial & .048 & 2.948 & .028 & .016 & .987 \\
X1.M1 & -.001 & .039 & -.005 & -.014 & .989 \\
X1.M2 & -.032 & .024 & -.532 & -1.338 & .182 \\
X1.M3 & -.133 & 2.955 & -.077 & -.045 & .964 \\
\hline Sumber: Data diolah, 2019 & & & & &
\end{tabular}

Pada Tabel 4. dapat dilihat bahwa nilai signifikansi dari variabel financial distress sebesar 0,190, dewan komisaris independen sebesar 0,968, kepemilikan institusional sebesar 0,610, kepemilikan manajerial sebesar 0,987 variabel 
interaksi $\mathrm{X}_{1} \cdot \mathrm{M}_{1}$ sebesar 0,989 , variabel interaksi $\mathrm{X}_{1} \cdot \mathrm{M}_{2}$ sebesar 0,182 , dan variabel interaksi $\mathrm{X}_{1} \cdot \mathrm{M}_{3}$ sebesar 0,964 . Nilai tersebut lebih besar dari 0,05 yang berarti tidak terdapat pengaruh antara variabel bebas terhadap absolute residual. Bedasarkan hasil tersebut, model yang dibuat tidak mengandung gejala heteroskedastisitas.

Tabel 5.

Hasil Uji Wald

\begin{tabular}{llllllll}
\hline & & B & S.E. & Wald & Df & Sig. & $\operatorname{Exp}(\mathrm{B})$ \\
\hline \multirow{2}{*}{ Step 1 ${ }^{\mathrm{a}}$} & X1 & -.926 & .256 & 13.121 & 1 & .000 & .396 \\
& Constant & -2.000 & .452 & 19.598 & 1 & .000 & .135 \\
\hline
\end{tabular}

Sumber: Data diolah, 2019

Tabel 5. menunjukkan hasil pengujian dengan regresi pada taraf kesalahan 5 persen. Hasil pengujian regresi menghasilkan sebagai berikut:

$$
\mathrm{Y}=-2.00-0.926 X_{1}+\mathrm{e}
$$

Bedasarkan model regresi yang terbentuk, dapat diinterpretasikan hasil sebagai berikut: Nilai konstanta sebesar $-2,00$ menyatakan bahwa jika bila tidak mengalami financial distress dinyatakan sama dengan nol, maka tidak akan menerima opini audit going concern. Nilai koefisien regresi $\mathrm{X}_{1}$ yaitu financial distress sebesar -0,926 menunjukkan bila financial distress naik satu satuan, maka opini audit going concern akan mengalami penurunan sebesar 0,926.

Tabel 6. Overall Model Fit

\begin{tabular}{|c|c|c|c|c|c|}
\hline \multicolumn{6}{|c|}{$2 \log$ likelihood } \\
\hline \multicolumn{3}{|c|}{ blok number $=0$} & \multicolumn{3}{|c|}{ blok number $=1$} \\
\hline Step & 1 & 104.211 & Step 1 & 1 & 89.762 \\
\hline \multirow[t]{6}{*}{0} & 2 & 87.851 & & 2 & 59.266 \\
\hline & 3 & 86.325 & & 3 & 51.335 \\
\hline & 4 & 86.296 & & 4 & 49.493 \\
\hline & 5 & 86.296 & & 5 & 49.329 \\
\hline & 6 & 86.296 & & 6 & 49.328 \\
\hline & & & & 7 & 49.328 \\
\hline
\end{tabular}

Sumber: Data diolah, 2019 
Hasil uji Keseluruhan Model (Overal Model Fit) pada Tabel 6. diatas menunjukkan bahwa angka -2 log likelihood pada awal (blok number $=0$ ) dan -2 log likelihood pada blok number $=1$ mengalami penurunan, hal ini menunjukkan model regresi yang baik.

Tabel 7.

Hasil Uji Hosmer and Lemeshow Test

\begin{tabular}{llll}
\hline Step & Chi-square & Df & Sig. \\
\hline 1 & 13.674 & 8 & .091 \\
\hline
\end{tabular}

Sumber: Data diolah, 2019

Nilai Chi Square tabel untuk DF 8 pada taraf signifikansi 0,05 adalah sebesar 14,067. Karena nilai Chi Square Hosmer and Lemeshow hitung 13,674< Chi Square table 14,067 atau nilai signifikansi sebesar 0,091 lebih besar dari 0,05, sehingga menerima $\mathrm{H}_{0}$, yang menunjukkan bahwa model dapat diterima dan pengujian hipotesis dapat dilakukan sebab ada perbedaan yang tidak signifikan antara model dengan nilai observasinya.

Tabel 8.

Nagelkerke R Square Test

\begin{tabular}{clll}
\hline Step & -2 Log likelihood & Cox \& Snell R Square & Nagelkerke R Square \\
\hline 1 & $49.328^{\mathrm{a}}$ & .161 & .479 \\
\hline Sumber: & Data diolah, 2019 & &
\end{tabular}

Hasil uji pada Tabel 8. diatas memberikan hasil dimana diperoleh nilai Nagelkerke $R$ Square adalah sebesar 0,479. Hal tersebut menunjukkan bahwa variasi opini audit going concern dapat dipengaruhi secara signifikan oleh variabel financial distress sebesar 47,9 persen, sedangkan sisanya sebesar 52,1 persen dijelaskan oleh faktor-faktor lain yang tidak dijelaskan dalam model penelitian. 
Bedasarkan Tabel 9. dapat disusun persamaan regresi untuk menguji good corporate governance sebagai pemoderasi pengaruh financial distress pada opini audit going concern sebagai berikut:

$$
\begin{aligned}
\mathrm{Y}= & 0,518-0,180 \mathrm{X}_{1}+0,228 \mathrm{M}_{1}+0,685 \mathrm{M}_{2}+19,204 \mathrm{M}_{3}-0,132 \mathrm{X}_{1} \cdot \mathrm{M}_{1}+0,261 \\
& \mathrm{X}_{1} \cdot \mathrm{M}_{2}-18,425 \mathrm{X}_{1} \cdot \mathrm{M}_{3}+\mathrm{e}
\end{aligned}
$$

Tabel 9.

\begin{tabular}{|c|c|c|c|c|c|}
\hline \multirow[t]{2}{*}{ Model } & \multicolumn{2}{|c|}{$\begin{array}{c}\text { Unstandardized } \\
\text { Coefficients }\end{array}$} & \multirow{2}{*}{$\begin{array}{c}\begin{array}{c}\text { Standardized } \\
\text { Coefficients }\end{array} \\
\text { Beta } \\
\end{array}$} & \multirow[b]{2}{*}{$T$} & \multirow[b]{2}{*}{ Sig. } \\
\hline & $B$ & Std. Error & & & \\
\hline $1 \quad$ (Constant) & .518 & .081 & & 6.352 & .000 \\
\hline Financial Distress & -.180 & .024 & -1.995 & -7.649 & .000 \\
\hline Dewan Komisaris Independen & .228 & .146 & .108 & 1.557 & .121 \\
\hline Kepemilikan Institusional & -.685 & .096 & -.492 & -7.136 & .000 \\
\hline Kepemiliknan Manajerial & 19.204 & 3.597 & 5.984 & 5.339 & .000 \\
\hline X1.M1 & -.132 & .047 & -.610 & -2.785 & .006 \\
\hline X1.M2 & .261 & .029 & 2.324 & 8.957 & .000 \\
\hline X1.M3 & -18.425 & 3.605 & -5.747 & -5.111 & .000 \\
\hline R Square & 0,577 & & & & \\
\hline Adjusted R Square & 0,562 & & & & \\
\hline F Statistik & 39,187 & & & & \\
\hline Signifikansi & 0,000 & & & & \\
\hline
\end{tabular}

Hasil Analisis Regresi Moderasi

Berdasarkan persamaan regresi tersebut dapat diinterpretasikan sebagai berikut: Nilai konstanta $(\alpha)$ sebesar 0,518 menyatakan bahwa jika variabel financial distress, dewan komisaris independen, kepemilikan institusional, dan kepemilikan manajerial dinyatakan sama dengan konstan pada angka nol, maka nilai opini audit going concern meningkat sebesar 0,518.

Nilai koefisien $\left(\beta_{1}\right)$ variabel financial distress memiliki koefisien bernilai negatif. Nilai koefisien ini menjelaskan bahwa setiap kenaikan variabel financial distress maka opini audit going concern akan mengalami penurunan dengan asumsi nilai variabel independen lainnya konstan. Nilai koefisien $\left(\beta_{2}\right)$ variabel dewan komisaris independen memiliki koefisien bernilai positif. Nilai koefisien 
ini menjelaskan bahwa setiap kenaikan variabel dewan komisaris independen maka opini audit going concern akan mengalami kenaikan dengan asumsi nilai variabel independen lainnya konstan.

Nilai koefisien $\left(\beta_{3}\right)$ variabel kepemilikan institusional memiliki koefisien bernilai negatif. Nilai koefisien ini menjelaskan bahwa setiap kenaikan variabel kepemilikan instituisonal maka opini audit going concern akan mengalami penurunan dengan asumsi nilai variabel independen lainnya konstan. Nilai koefisien $\left(\beta_{4}\right)$ variabel kepemilikan manajerial memiliki koefisien bernilai positif. Nilai koefisien ini menjelaskan bahwa setiap kenaikan variabel kepemilikan manajerial maka opini audit going concern akan mengalami kenaikan dengan asumsi nilai variabel independen lainnya konstan.

Nilai koefisien $\left(\beta_{5}\right)$ interaksi antara financial distress dengan dewan komisaris independen $\left(\mathrm{X}_{1} \mathrm{M}_{1}\right)$ sebesar $-0,132$ memiliki arti bahwa apabila interaksi antara financial distress dengan dewan komisaris independen meningkat sebesar satu satuan, maka opini audit going concern akan menurun sebesar 0,132 satuan, dengan asumsi variabel independen lainnya konstan. Nilai koefisien $\left(\beta_{6}\right)$ interaksi antara financial distress dengan kepemilikan institusional $\left(\mathrm{X}_{1} \mathrm{M}_{2}\right)$ sebesar 0,261 memiliki arti bahwa apabila interaksi antara financial distress dengan kepemilikan institusional meningkat sebesar satu satuan, maka opini audit going concern akan meningkat sebesar 0,261 satuan, dengan asumsi variabel independen lainnya konstan.

Nilai koefisien $\left(\beta_{7}\right)$ interaksi antara financial distress dengan kepemilikan manajerial $\left(\mathrm{X}_{1} \mathrm{M}_{3}\right)$ sebesar $-18,425$ memiliki arti bahwa apabila interaksi antara 
financial distress dengan kepemilikan manajerial meningkat sebesar satu satuan, maka opini audit going concern akan menurun sebesar 18,425 satuan, dengan asumsi variabel independen lainnya konstan.

Hasil uji F (Ftest) pada Tabel 9. menunjukkan bahwa besarnya nilai $\mathrm{F}$ hitung sebesar 39,187 dengan nilai signifikansi $\mathrm{P}$ value 0,000 lebih kecil dari $\alpha=$ 0,05 , ini berarti model yang digunakan pada penelitian ini adalah layak. Hasil ini memberikan makna bahwa seluruh variabel independen mampu memprediksi atau menjelaskan fenomena opini going concern pada perusahaan manufaktur yang terdaftar di Bursa Efek Indonesia dari tahun 2015-2017. Variabel financial distress, komisaris independen, kepemilikan institusional, kepemilikan manajerial dan variabel interaksi $\mathrm{X}_{1} \cdot \mathrm{M}_{1}, \mathrm{X}_{1} \cdot \mathrm{M}_{2}, \mathrm{X}_{1} \cdot \mathrm{M}_{3}$ secara simultan berpengaruh signifikan terhadap opini going concern pada perusahaan manufaktur yang terdaftar di Bursa Efek Indonesia dari tahun 2015-2017.

Hasil uji koefisien determinasi memberikan hasil dimana diperoleh besarnya adjusted $R^{2}$ (koefisien determinasi yang telah disesuaikan) pada Tabel 4.9 adalah 0,562. Hal ni berarti variasi opini going concern pada perusahaan manufaktur yang terdaftar di Bursa Efek Indonesia dari tahun 2015-2017 dapat dijelaskan oleh variabel financial distress, komisaris independen, kepemilikan institusional, kepemilikan manajerial dan variabel interaksi $X_{1} . X_{2}, X_{1} . X_{3}, X_{1} . X_{4}$ sebesar 56,2 persen, sedangkan sisanya sebesar 43,8 persen dijelaskan oleh faktor-faktor lain yang tidak dijelaskan dalam model penelitian.

Berdasarkan hasil uji regresi logistik pada Tabel. 5 mengenai pengaruh financial distress pada opini audit going concern menunjukkan koefisien regresi 
wald negatif sebesar sebesar -0,926 dengan nilai signifikansi sebesar $0,000<$ 0,050 yang berarti $\mathrm{H}_{1}$ diterima. Hasil ini mempunyai arti bahwa financial distress berpengaruh negatif dan signifikan terhadap opini audit going concern.

Variabel financial distress yang diukur dengan model kebangkrutan Altman Z-Score menyatakan semakin rendah score perusahaan maka semakin buruk kondisi keuangan perusahaan. Hasil penelitian ini sesuai dengan teori sinyal dimana kondisi financial distress yang dialami perusahaan memberikan sinyal kepada auditor sehingga auditor meragukan keberlangsungan perusahaan. sependapat dengan penelitian Yuliani (2017) dan Dewi (2018) yang menunjukkan bahwa financial distress berpengaruh negatif terhadap opini audit going concern.

Berdasarkan hasil uji analisis regresi moderasi pada Tabel 9. menunjukkan bahwa nilai koefisien regresi dewan komisaris independen $(\beta 2)$ positif sebesar 0,228 dengan nilai signifikansi sebesar 0,121 sedangkan nilai koefisien regresi variabel interaksi $X_{1} \cdot M_{1}\left(\beta_{5}\right)$ negatif sebesar $-0,132$ dengan nilai signifikansi $0,006<0,050$. Berdasarkan hasil uji menunjukkan nilai koefisien regresi memiliki arah yang berlawanan, maka dapat disimpulkan bahwa variabel dewan komisari independen merupakan variabel moderasi yang memperlemah pengaruh financial distress pada opini audit going concern.

Hasil penelitian sesuai juga dengan teori agensi dimana perbedaan kepentingan antara pihak agen dan prinsipal mengharuskan auditor untuk lebih berhati-hati dalam memberikan opininya. Berdasarkan uji regresi moderasi yang dilakukan menunjukkan bahwa keberadaan dewan komisaris dalam perusahaan mampu memperlemah peluang perusahaan memperoleh opini audit going concern 
akibat financial distress yang dialami perusahaan. Hal ini selaras dengan penelitian yang dilakukan oleh Setiawan (2011) yang membuktikan bahwa semakin besar proporsi dewan komisaris independen mampu mengurangi kemungkinan pemberian opini audit going concern.

Berdasarkan hasil uji analisis regresi moderasi pada Tabel 4.9 menunjukkan bahwa nilai koefisien regresi kepemilikan institusional $\left(\beta_{3}\right)$ negatif sebesar $-0,685$ dengan nilai signifikansi sebesar 0,000 sedangkan nilai koefisien regresi variabel interaksi $X_{1} \cdot M_{2}\left(\beta_{6}\right)$ positif sebesar 0,261 dengan nilai signifikansi 0,000<0,050. Berdasarkan hasil uji menunjukkan nilai koefisien regresi memiliki arah yang berlawanan, maka dapat disimpulkan bahwa variabel kepemilikan institusional merupakan variabel moderasi yang memperlemah pengaruh financial distress pada opini audit going concern.

Hasil penelitian menunjukkan bahwa kepemilikan insitusional yang cenderung sebagai pemegang saham mayoritas dalam kepemilikan saham perusahaan mampu memperlemah peluang perusahaan memperoleh opini audit going concern meskipun perusahaan mengalami financial distress. Hal tersebut sesuai dengan teori agensi, dimana dengan adanya kepemilikan manajerial dapat mengurangi kemungkinan pihak agen melakukan manipulasi laporan keuangan dan memberikan informasi yang sesungguhnya kepada pihak prinsipal. Hasil ini selaras dengan penelitian yang dilakukan Nurpratiwi dan Shiddiq (2014) yang menyatakan bahwa kepemilikan institutusional mempengaruhi opini audit going concern. 
Berdasarkan hasil uji analisis regresi moderasi pada Tabel 9. menunjukkan bahwa nilai koefisien regresi kepemilikan manajerial ( $\beta 4)$ positif sebesar 19,204 dengan nilai signifikansi sebesar 0,000 dan nilai koefisien regresi variabel interaksi $X_{1} \cdot M_{3}\left(\beta_{7}\right)$ negatif sebesar $-18,425$ dengan nilai signifikansi $0,000<$ 0,050. Berdasarkan hasil uji menunjukkan nilai koefisien regresi memiliki arah yang berlawanan, maka dapat disimpulkan bahwa variabel kepemilikan manajerial merupakan variabel moderasi yang memperlemah pengaruh financial distress pada opini audit going concern.

Hasil penelitian menunjukkan bahwa kepemilikan saham oleh manajemen dalam perusahaan mampu memperlemah peluang perusahaan memperoleh opini audit going concern meskipun perusahaan mengalami financial distress. Hal tersebut memberikan sinyal positif kepada auditor sehingga menurunkan kemungkinan perusahaan memperoleh opini audit going concern meskipun perusahaan mengalami financial distress. Hasil ini selaras dengan penelitian Nurhaeni (2010) yang menyatakan kepemilikan manajerial mempengaruhi opini audit going concern.

\section{SIMPULAN}

Bedasarkan hasil pembahasan penelitian dapat disimpulkan sebagai berikut: Hasil penelitian membuktikan bahwa variabel financial distress yang berpengaruh negatif terhadap opini audit going concern artinya semakin tinggi score perusahaan maka semakin rendah kemungkinan penerimaan opini audit going concern. Hasil penelitian membuktikan bahwa dewan komisaris independen, 
kepemilikan institusional dan kepemilikan manajerial mampu memperlemah pengaruh financial distress pada opini audit going concern artinya penerapan good corporate governance pada perusahaan mampu memperlemah pengaruh financial distress terhadap opini audit going concern. Penelitian ini hanya menggunakan 3 proksi good corporate governance, sehingga penelitian berikutnya diharapkan menggunakan proksi lainnya guna memperluas variabel yang digunakan.

\section{REFERENSI}

Adjani, E. M. A. D. (2013). Analisis Pengaruh Corporate Governance Terhadap Kemungkinan Pemberian Opini Audit Going Concern oleh Auditor Independen.

Agung, G., Intan, A., Sari, P., Bagus, I., \& Astika, P. (2018). Pengaruh Opini Going Concern, Financial Distress, dan Kepemilikan Institusional Pada Auditor Switching Fakultas Ekonomi dan Bisnis Universitas Udayana (Unud), Bali , Indonesia.

Agusti, C. P. (2013). Analisis Faktor-Faktor yang Memprediksi Kemungkinan Terjadinya Financial Distress. Semarang: Universitas Diponogoro.

Al. Haryono Jusup. 2013. Dasar-Dasar Akuntansi Jilid 1. Edisi 7. Yogyakarta: STIE YKPN.

Arisman, A. (2016). Pengaruh Corporate Governance Terhadap Opini Audit Going Concern Dengan Tekanan Keuangan Sebagai Pemoderasi (Studi Empiris Perusahaan Manufaktur Yang Terdaftar di Bursa Efek Indoneisa Tahun 2014-2016), (x), 1-20.

Ayu, I. G., Alansari, P., \& Badera, I. D. N. (2016). E-Jurnal Akuntansi Universitas Udayana Opini Audit Going Concern sebagai Pemoderasi Pengaruh Pertumbuhan Perusahaan dan Pergantian Manajemen Pada Auditor Switching., 862-886.

Brooks, Lily Zheng. (2015). Audit Engagement Risk and The Propensity of Issuing Going -Concern-Opinion-Does Audit Firm Tenure Matter. Journal of International Business and Economics, 3 (2), 17-42. 
Chen, K. C., Church, B. K. (1992). Debt on Debt Obligations and The Issuance of Going Concert Report. Auditing : Journal Practice and Theory, Fall. 30-49.

Dewayanto, T. (2011). Penerimaan Opini Audit Going Concern Terdaftar pada Bursa Efek Indonesia, 81-104.

Dewi, Nyoman Stari. (2018). Pengaruh Financial Distress dan Debt Default pada Opini Going Concern., 1223-1252.

Eduk, Kristina Deventy, dan Nugraeni. (2015). "Pengaruh Mekanisme Corporate Governance Terhadap Pemberian Opini Audit Going Concern (Studi Empiris pada Perusahaan Manufaktur yang Terdaftar di Bursa Efek Indonesia Tahun 2011-2013)". Jurnal Riset Akuntansi Mercu Buana(JRAMB), Vol.1, No.1, Universitas Mercu Buana Yogyakarta.

Emery and Barker. (2007). The Effect of Transactional and Transformational Leadership Style on The Organizational Commitment and Job Satisfaction at Customer Contact Personnel. Journal of Organizational Culture, Communication and Conflict. Vol.11 No.1, pp. 77-90.

Emrinaldi. (2007). Analisis Pengaruh Praktek Tata Kelola Perusahaan (Corporate Governance) Terhadap Kesulitan Keuangan Perusahaan (Financial Distress) : Suatu Kajian Empiris. Jurnal Bisnis dan Akuntansi, Vol. 9, No. 1.

Foroghi, Daruosh and Amir Mirshams Shahshahani. (2012). Audit Firm Size and Going Concern Reporting Accuracy, Interdisciplinary Journal of Contemporary Research in Business 3 (January): 1093-1098.

Helena, S. (2016). Pengaruh Corporate Governance Terhadap Financial Distress, (Studi Pada Perusahaan Transportasi Yang Terdaftar di Bursa Efek Indonesia Periode 2013-2016 ), 60(2), 143-152.

Ikatan Akuntan Publik Indonesia. (2011). Standar Profesional Akuntan Publik. Jakarta: Salemba Empat.

Januarti, I., \& Diponegoro, U. (2009). Analisis Pengaruh Faktor Perusahaan, Kualitas Auditor, Kepemilikan Perusahaan Terhadap Penerimaan Opini Audit Going Concern (Perusahaan Manufaktur Yang Terdaftar di Bursa Efek Indonesia ), 1-26.

Jensen, M. C., \& Meckling, W. H. (1976). Theory of the Firm: Managerial Behavior, Agency Costs and Ownership Structure Theory of the Firm: Managerial Behavior, Agency Costs and Ownership Structure. 
Li, Hong Xia, Zong Jun Wang and Xiao Lan Deng. (2008). Ownership Independent Directors, Agency Cost and Financial Distress: Evidence from Chinese Listed Companies. Vol.8.

Merkusiwati, Ni Kt. Lely dan Putri, Ni Wayan Krisnayanti Arwinda. (2014). Pengaruh Mekanisme Corporate Governance, Likuiditas, Leverage, dan Ukuran Perusahaan pada Financial Distress. E-jurnal Akuntansi Universitas Udayana.

Mulyadi. 2010. Auditing. Edisi ke 6 buku 1, Jakarta: Salemba Empat.

Mulyani, Sri., Darminto., dan M.G WI Endang N.P. 2013. Pengaruh Karakteristik Perusahaan, Koneksi Politik, dan Reformasi Perpajakan Terhadap Penghindaran Pajak (Studi Pada Perusahaan Manufaktur yang Terdaftar di Bursa Efek Tahun 2008-2012). Jurnal Universitas Brawijaya.

Nariman, Agustpaosa. (2015). Pengaruh Ukuran Kantor Akuntan Publik Terhadap Opini Going Concern dan Earnings Response Coefficients (ERC) pada Perusahaan Manufaktur yang Terdaftar di BEI Tahun 2011-2013. Jurnal Akuntansi, 19(2), hal. 160-178.

Nurpratiwi Vidya dan Shiddiq Nur Rahardjo. (2014). Analisis Pengaruh Ukuran Perusahaan, Struktur Kepemilikan, Faktor Komite Audit, Rasio Profitabilitas, dan Rasio Aktivitas Terhadap Penerimaan Opini Audit Going Concer. Diponegoro Journal of Accounting. Volume 3, No. 3. Halaman 115.

Platt, H, \& Platt, M.B. (2002) Predicting Financial Distress. Journal of Financial Service Professionals, 56: 12-15.

Putri, A. A. S., Sari, P., Bagus, I., \& Astika, P. (2015). Moderasi Good Corporate Governance pada Pengaruh Antara Leverage dan Manajemen Laba, 752769.

Rakatenda. (2016). Opini Audit Going Concern dan Faktor-Faktor yang Mempengaruhinya, 16, 1347-1375

Richardson, V.J. (1998). Information Asymmetry and Earnings Management: Some Evidence. Dissertation, University of Kansas, March.

Sadewi, N. I., \& Suputra, I. D. G. D. (2016). E-Jurnal Akuntansi Universitas Udayana Integritas sebagai Pemoderasi Pengaruh Expectation Gap pada Kinerja Auditor, 1141-1167.

Sari, Ni Luh Kadek Merta., dan I G.A.M. Asri Dwija Putri. (2016). Kemampuan Profitabilitas Memoderasi Pengaruh Likuiditas dan Leverage Terhadap 
Ketut Memi Wulandari dan Ketut Muliartha. Good ...

Financial Distress. E-Jurnal Akuntansi Universitas Udayana, 5 (10), hal. 3419-3448.

Shleifer, A., and R.W. Vishny. 1986. Large Shareholders and Corporate Control. The Journal of Political Economy. Vol 94 (31): 461-488.

Setiawan, Teguh Heri. (2011). Analisis Pengaruh Faktor Perusahaan, Kualitas Audit, dan Mekanisme Good Corporate Governance Terhadap Penerimaan Opini Audit Going Concern. Skripsi S-1 Fakultas Ekonomi, Universitas Diponegoro.

Spence, Michael. (1973) “Job Market Signaling”. The Quarterly Journal of Economics, 87,( 3) (Aug., 1973), pp. 355-374. The MIT Press. 